\title{
The Construction of Religiosity in Social Media: Response of Ambon's Millennial Generation to Online Sermons
}

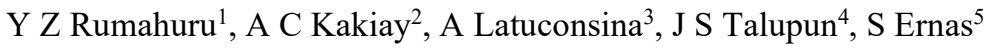 \\ Institut Agama Kristen Negeri Ambon, Poka-Ambon ${ }^{1}$ \\ Institut Agama Kristen Negeri Ambon, Halong Atas Ambon ${ }^{2}$ \\ Institut Agama Islam Negeri Ambon, Batu Merah Sirimau Ambon ${ }^{3}$ \\ Institut Agama Kristen Negeri Ambon, Batu Gantung Ambon ${ }^{4}$ \\ Institut Agama Islam Negeri Ambon, Batu Merah Sirimau Ambon ${ }^{5}$ \\ \{yz rumahuru@iaknambon.ac.id ${ }^{1}$, achkakiay@iaknambon.ac.id ${ }^{2}$, adamlatuconsina@iainambon.ac.id ${ }^{3}$, \\ is talupun@iaknambon.ac.id ${ }^{4}$, saidinernas@iainambon.ac.id $\left.{ }^{5}\right\}$
}

\begin{abstract}
Social media is not used only for entertainment or expanded communication networks and business, but also for the construction and development of religiosity, especially for the millennial or young people who are closer to gadget. The millennial generation use social media more to find out various things, ranging from general information, communication between people, self-exploration and identity construction, career development, to strengthening its religious aspects or religiosity. This paper will analyze how young Muslims and Christians in the city of Ambon respond to the phenomenon of strengthened religiosity in social media, especially through religious lectures and online sermons. Some of them are also fond of following the news on religiosity materials through online sermons. This paper will discuss also how the these online sermons influence the construction and development of millennial religiosity. To find out the responses of Ambon's youths, the authors conducted a survey to young Muslims and Christians in Ambon, and the results will be analyzed in a qualitative and descriptive manner. This study found that online preaching is very popular among the millennial because it helps to answer their concerns about other religious and social issues anytime.
\end{abstract}

Keywords: Social Media, Millennial, Religiosity, Sermons

\section{Introduction}

Millennial generation that gave birth to Generation Z, whether we realize it or not, has now determined individual's involvement in community groups. The condition influences their lifestyles and religious attitudes. In fact, the millenials are young people who are currently very influential in society [1]. Social reality in this digital age shows that the virtual world has replaced the role of many things in the real world. An interesting phenomenon is the construction and the development of religiosity especially through religious lectures and various types of religious preaching in social media, which in this paper are referred to as 
online sermons. It is assumed that online sermons have the potential to shift the existence of face-to-face sermons. The millennials find face-to-face religious lectures or sermons no longer interesting because they have to waste their time to come to a place or community gathering. Religious lecturers or sermons available online are more appealing to them. Most millennials, especially Generation $\mathrm{Z}$, tend to consider lectures in religious gatherings or rituals as confessional [2].

In the context of Indonesia, and specifically in Maluku, the category of millennial generation that becomes the focus of this study is interesting to observe because they are now taking a big role in society, producing a new generation of new values for the nation. The people who belong to the millennial generation are young people who play a role in society. In addition, they will greatly determine the existence and characters of every religion in implementing religious values or religiosity today. Electronic scripture, religious lectures or sermons are now available online as demanded by many millennial generations, including Muslim millennials in Ambon City. Does this phenomenon affect their religiosity and have an impact on their real lives in Ambon City? This question will be examined in this paper.

This paper aims to explain the phenomenon of the Ambon's millennials who are now fond of online sermons and its influence on the construction of their religiosity. The questions being addressed in this paper are: First, how young people in Ambon City respond to the phenomenon of construction and the strengthening of religiosity in social media, especially online sermons. Second, how online sermons have influence on the construction and development of religiosity among the millennials. Before answering the two questions, this paper set up two assumptions: (1) the millennials tend to preferably hear online sermons rather than face-to-face ones in community gatherings, and (2) online sermons have their own influence (positive and negative) on the lives of the millennials.

Before going further into details, it is necessary here to highlight some important concepts used in this research.

The first concept is religiousity. It is closely related to the presence of an organized religious sense within a religious community to enhance their faith and beliefs. Religiosity can be used as a way to explain the spirituality of certain individuals and groups. In this case, spirituality is a broad dimension of religiosity (the difference between spirituality and religiosity can be seen in Ratnakar and Nair: 2012). The root of religiosity is religion. It is not surprising that religious groups tend to look for various ways to build religiosity of their members, including utilizing cyberspace for the construction of religiousity.

Glock and Stark viewed religiosity to have a close relationship with religious aspects in a person. Glock and Stark [2] suggested five dimensions of religiosity: 1. belief; 2. religious practice; 3. experience; 4. knowledge; and 5. consequence. The belief dimension is an assumption that religiosity is formed by certain beliefs recognized as doctrines. In this regard, each religion shows its fanaticism in maintaining its beliefs. Thus, it is not surprising that each religion tends to defend its religious doctrines (akidah) and traditions. The religious practice dimension emphasizes that religiosity has a close relationship with religious practices that manifest in two variants: ritual and obedience or piety as a religious commitment. In practice, this dimension is very influential on other dimensions. The experience dimension is religious experience that is always owned by every individual or group of religion, including feelings, views or subjective knowledge and various situations experienced by the individuals and the groups related to the existence of a transcendent subject or reality of divinity. The knowledge dimension is an assumption that every religious person has minimal knowledge about his her basic religious beliefs, doctrines, rites and traditions. The consequence dimension is an 
assumption that there are consequences of obedience and non-compliance with the adopted religious beliefs.

The second concept is Millennial Generation. Manheim (1952) studied generation differences and defined generation as a social construction in which a group of people shares the same age and historical experience. William Strauss (1991) and Kupperschmidt (2000) later developed and popularized theories about subsequent generation differences. As for the emergence of the term 'millennial', it was first coined by William Strauss and Neill in Millennials Rising: The Next Great Generation (2000). They have created and used this term since 1987. The term refers to children who were born in 1982 and at school age so that they graduated from high school on average in 2000, a period that marked the birth of a new generation. In line with Strauss and Neill, Elwood Callon (2008) mentioned that millennial generation was born between 1983 - 2001. Millennial generation was also referred to as Generation Y, a term widely used especially in the editorials of major newspapers in America in 1993.

The third concept is social media. The term 'media' is generally understood as a communication tool [3], [4]. In everyday people's lives, when they hear the word media, what comes to mind is the means that are accompanied by technology. For example, newspapers are a representation of print media, while radio and television are representations of electronic media, and the internet is represented by online media or the network [5]. The word media can be also understood by looking at a communication process, because the media is a container for carrying messages from the communication process [6], [7].

It has been commonly known that communication process requires three things: object, organ and medium. These three aspects cannot be separated when witnessing and carrying out a communication process in the community. The word 'social' theoretically becomes the realm of sociology, but in communication, it is associated with information and awareness [5]. In different thoughts about social media, social media is seen from the development of how the individuals relate themselves to media tools.

\section{Method}

Ambon, which is the research site in this study, is an old city in eastern Indonesia that represents a modern life due to a high rate of gadget usage. In the Indonesian context, when viewed from the position of the national capital in Jakarta, Ambon is one of the small cities in all corners of Indonesia. However, the development and creativity of young people or millennial generation in this city is not inferior to those in Jakarta or other big cities in Indonesia. The choice of millennial generation in Ambon City as a research focus is also based on the assumption that in Ambon, Muslims and Christians have the same religious observance and fanaticism. This is one factor why religious approaches in Ambon are more effectively used than elsewhere in Indonesia.

This paper is a field research in Ambon City, using qualitative methods with a phenomenological approach. The type of data used in this study is qualitative, in the form of observations and interviews, and studies of available documents. To find the information used as data for this study, the authors chose informants for young people from two major religious groups in Ambon City, Muslims and Christians, to be included in the category of millennial generation as stated before, with ages ranging from 20 to 35 years-old.

The data collection techniques are interviews. The strategy used in the interviews is to a snowball technique, where the researchers try to lure informants to express various matters related to the research focus with inducement during which the informants can tell stories 
according to their language styles, while referring to other colleagues. In relation to this, interview guidelines have been made to direct the conversations that may provide answer the two research questions. Because the data is qualitative, the analysis technique used is also qualitative, using an interpretive or hermeneutic analysis method to understand the research problem being examined. For this reason, all the data collected is grouped, interpreted and given meaning. The analysis results are presented in the form of a description.

\section{Result and Discussion}

This research found that the average millennials in Ambon see online sermons as one of the important medias for the construction and development of their religiosity, although not all of them consider that online sermons can replace face-to-face sermons in the communal rituals of each religion. However, the position of online sermons is considered more interesting and exciting. This study also discovered the following five main aspects during the interviews with each informant. The five aspects are summarized from various answers related to questions about their responses to the online sermons that they followed and the effects on the construction of their religiosity.

Table 1. Responses of Millennial Muslims in Ambon to Online Sermon and Its Effects

$$
\text { Response to Online Sermons }
$$

\section{Online Effects}

$\begin{array}{ll}\begin{array}{l}\text { Online sermons help them know better the } \\ \text { teachings of Islam }\end{array} & \text { Increasing religious motivation } \\ \begin{array}{l}\text { Online sermons are interesting and } \\ \text { enlightening }\end{array} & \text { Changing religious insights } \\ \begin{array}{l}\text { Following the speeches/sermons online on } \\ \text { social media is amazing. }\end{array} & \begin{array}{l}\text { Changing religious behaviors (including how } \\ \text { to dress, behave or speak so that you can } \\ \text { accept something with pleasure) }\end{array} \\ \text { Becoming a more elegant propaganda media } & \begin{array}{l}\text { Changing perspectives on conventional } \\ \text { preaching }\end{array} \\ \begin{array}{l}\text { Illuminating or guiding people in } \\ \text { understanding Islamic teachings. }\end{array} & \begin{array}{l}\text { Changing worship intentions because they are } \\ \text { encouraged to exercise their rights as } \\ \text { Muslims, and abandon His prohibitions. }\end{array}\end{array}$

Online sermons help them know better the Muslims, and abandon His prohibitions.

Table 2. Responses of Millennial Christians in Ambon to Online Sermon and Its Effects 
Response to Online Sermons

Effects of Online Sermons

Online preaching is very helpful in Enhancing religious understanding understanding the teachings of Christianity

Online sermons are fun, cool and in my Soothing and exciting online sermons preference

Online preaching is easier to understand and Changing yourself on what the Bible wants can provide guidance

Online preaching is good for people who are really busy and or who are lazy to go to church

Filling the emptiness of the soul with the word at any time, without leaving a routine task.

The use of social media for the preaching of Making many people get help and repent the words (= online sermon) is very helpful

In general, the results presented in these two tables show that the millennial generation of Islam and Christianity in Ambon gave various answers in response to the construction and development of religiosity through online sermons. There are similarities in the answers although they were expressed in different ways and styles. The similar responses, in the authors' opinion, represent the dynamics and existence of millennial generation who are more open, free in rhetoric, and less concerned with formality. Their language style was straightforward. They liked to use slang and flexible terms, which were understandable for young people. When the authors conducted an interview with them, both young Muslims and Christians showed a level of intimacy. They easily adapted to the place and time when invited to meet and they were dressing in a trendy style. When informal interviews were conducted, the authors felt happy because when speaking, there was no rigidity or reluctance to tell the story as it was, even though it was related to the aspects of religious doctrines or akidah.

In regard with the responses, as stated before, the research found that: first, the average young or millennial generation in Ambon tends to take part in online sermons. Second, the media that are widely referred in attending online sermons are YouTube, Facebook, and Instagram. Third, young people in Ambon follow online religious sermons or lectures because (1) it provides them with information and knowledge about religion; (2) it can motivate them to change; (3) it can increase faith and religious awareness; (4) it makes them adapt to the time and the place; and (5) it helps them find answers to their problems.

The online sermon has positive effects on the construction and development of millennial generation religiosity in Ambon. It is interesting to mention here is that even though young people or millennial generation in Ambon City seemed to be ignorant and less involved in religious rituals followed by most of their parents, they get themselves active in following online sermons. The average informants interviewed about the effects of attending an online sermon gave a real example of how their experiences in following the online sermons have made them to change or repent. They said that online sermons have inspired and motivated them to change. In fact, through online sermons, they can build up life's principles that truly 
become the essence of their respective on religious teachings. The following are some statements quoted from the informants to show that the millennial generation in Ambon City benefits positively from attending an online sermon:

"Through online sermons, we can clearly know the steps in implementing religious teachings (Islam) and it can increase our religious motivation" (Rosmina, 23 years).

"By following an online sermon, it turns out that it can change me to be far better than before. The way of dressing, acting and speaking has changed so that you can receive something with pleasure" (Jaida, 22 years).

"I like to take part in religious preaching or online sermons because it helps me know a lot about religion, and thanks God it makes me calm" (R.M, 30 years).

"Online sermons can make me learn better about Christianity, even I can change myself into what is discussed in the sermon" (Selfone, 23 years).

"Online religious sermons or lectures that I join are very good because they contain religious messages that are good for humans. I am lazy to go to worship, but because of frequently attending this online program I can change my life and be on the right path" (Junita, 22 years).

Some of the millennial considered that even though online sermon is good and interesting, and seemingly able to replace face-to-face sermons, the latter would be still needed. This is especially related to the importance of involvement in the fellowship of each community. They emphasized that it is important to pay attention to the balance between the preaching and religious teachings that could reach all age categories of religious groups and the proper use of the media.

The research results mentioned earlier also indicate that being a small town on the outskirts of Eastern Indonesia and is assumed a bit late in terms of technological developments, it turns out that the young people in the City of Ambon do not left behind the millennial generation in other regions. They showed that they are very familiar with social media, including in terms of attending an online sermon. Even though their uses of social media are limited to YouTube, Instagram and Facebook or television, they can keep pace with the millennial generation elsewhere.

\section{Conclusion}

The discussion about the responses of young people or millennial generation in Ambon to the online sermons and their effects on their lives showed that online preaching is very popular among the millennial because it can help them, anytime and anyplace, answer their anxiety about religious and social issues they encounter with.

The results of this research showed that the young people or millennial generation in Ambon consciously and actively attend religious lectures or online sermons. Their interests in online sermons are motivated by a number of needs: curiosity and the need to increase knowledge about religion, the desire to increase faith and religious awareness, the limited time or laziness to join in conventional meetings, and the need to find solutions of the problems that they face. 
Although the Muslim and Christian millennial generation in Ambon City are more comfortable with online sermons than face-to-face ones, they still consider that face-to-face sermons are still needed. It is obvious that online sermons have a positive impact on the construction and development of religiosity of most Muslim and Christian millennial generations because it can change their attitudes according to their religious teachings. Online sermons have provided them with an up-to-date learning style and manner. However, the availability of a various content of online sermons has not been able to implant inclusive understanding to accept differences as a blessing or gift from the Creator.

\section{References}

[1] C. E. \& J. Schwarzbart, "Mengoptimalkan interaksi Multigenerasi dan menjadi pemimpin hebat," in Millionnials Who Manage, Jakarta: Kompas Gramedia, 2016, p. 18.

[2] C. Y. G. \& R. Stark, Religion and Society in Tension. Chicago: Rand McNally \& Campany, 1965.

[3] D. Laughey, Themes in Media Theory. New York: Open University Press, 2007.

[4] D. McQuail, Teori Komunikasi Masa. Jakarta: Penerbit Erlangga, 2003.

[5] R. Nasrulah, Media Sosial: Perspektif Komunikasi, Budaya, dan Sosioteknologi, 4th ed. Bandung: Simbiosa Rekatama Media, 2017.

[6] S. Moores, Media Theory, Thinking About Media and Communications. 2005.

[7] K. Wilyams, Understanding Media Theory. London: Arnold, 2003. 